\title{
PKM BIMBINGAN BELAJAR GRATIS BAGI SISWA KURANG MAMPU DI DESA SIALOGO KABUPATEN TAPANULI SELATAN
}

\author{
Darliana Sormin, Masdelima Azizah Sormin, Mira Rahma Yanti Sormin \\ Staf Pengajar Pendidikan Agama Islam, Universitas Muhammadiyah Tapanuli Selatan \\ suryapijar@yahoo.com
}

\begin{abstract}
This Community Partnership Program (PKM) discusses free tutoring for underprivileged students in the Huta Padang village, Southeast Padangsidimpuan sub-district. The purpose of this PKM is to provide additional learning for underprivileged students for free and to help students repeat the lessons they have learned at school. The number of participants in this PKM was 20 elementary school children who were classified as underprivileged. This service was carried out in Sialogo Village, South Tapanuli Regency. The method of implementation is in the form of tutoring which is carried out for 2 months. One of the results of this tutoring was a positive response from the parents of the participants and the enthusiasm of the children in following the tutoring from the beginning to the end of the tutoring. And the children can solve homework problems without having to argue with their parents. So that children continue to improve the quality of their learning at home. The output of this free tutoring activity is (1) Journals with ISSN. (2) The services of this free tutoring activity can provide additional knowledge for participants and can help children continue studying at home without having to be reminded of each parent.
\end{abstract}

Keywords: Tutoring, underprivileged students, Sialogo Village, South Tapanuli Regency

\begin{abstract}
Abstrak
Program Kemitraan Masyarakat (PKM) ini membahas tentang bimbingan belajar gratis untuk siswa kurang mampu di desa huta padang kecamatan Padangsidimpuan Tenggara. Tujuan dari PKM ini adalah memberikan pembelajaran tambahan untuk siswa yang kurang mampu secara gratis serta membantu siswa mengulang pembelajaran yang dipelajari mereka di sekolah. Jumlah Peserta pada PKM ini sebanyak 20 orang anak-anak tingkat SD yang tergolong kurang mampu. Pengabdian ini dilaksanakan di Desa Sialogo Kabupaten Tapanuli Selatan. Metode pelaksanaan yang dilakukan ialah berupa bimbingan belajar yang dilaksanakan selama 2 bulan. Hasil dari bimbingan belajar ini salah satunya sambutan positif dari orangtua peserta serta antusias anak-anak mengikuti bimbingan belajar dari awal hingga berakhirnya bimbingan belajar. Serta para anak-anak sudah mampu menyelesaikan soal pekerjaan rumah tanpa harus berdebat dengan orangtua. Sehingga anak-anak trus meningkatkan mutu belajarnya di rumah. Luaran yang dihasilkan dari kegiatan bimbingan belajar bratis ini ialah (1) Jurnal yang ber ISSN. (2) Jasa dari kegiatan bimbingan belajar gratis ini dapat memberikan tambahan pengetahuan pererta serta dapat membantu anak-anak trus belajar di rumah tanpa harus adanya teguran dari orangtua masing-masing.
\end{abstract}

Kata kunci: Bimbingan Belajar, Siswa kurang mampu, Desa Sialogo Kabupaten Tapanuli Selatan 


\section{PENDAHULUAN}

Kemiskinan merupakan masalah multidemensi Sulit mengukurnya sehingga perlu kesepakatan pendekatan pengukuran yang dipakai (Syawie, 2011). Kemiskinan atau kurang mampu sudah menjadi fenomena sepanjang sejarah kemanusiaan. Indonesia sebagai salah satu Negara yang kaya sumber daya alamnya namun tidak terlepas dari persoalan kemiskinan, akibat adanya salah memahami dan mengurus kemiskinan. Konsekuensi-nya telah membuat jutaan siswa-siswa Indonesia tidak bisa mengenyam pendidikan yang berkualitas dan menguatnya arus urbanisasi kekota. Implikasi lebih jauh kemiskinan telah membuat jutaan rakyat tidak dapat memenuhi kebutuhan pangan, sandang. Pemerintah Indonesia secara berkesinambungan terus melaksanakan berbagai program untuk meningkatkan kesejahteraan rakyat melalui serangkaian penanganan permasalahan fakir miskin dalam rangka memberdayakan keluarga miskin, karena fakir miskin dan anak terlantar harus dipelihara oleh Negara (UUD. RI 1945 pasal 34). Di bawah ini merupakan gambaran siswa kurang mampu yang ada di Desa Sialogo Kabupaten Tapanuli Selatan.

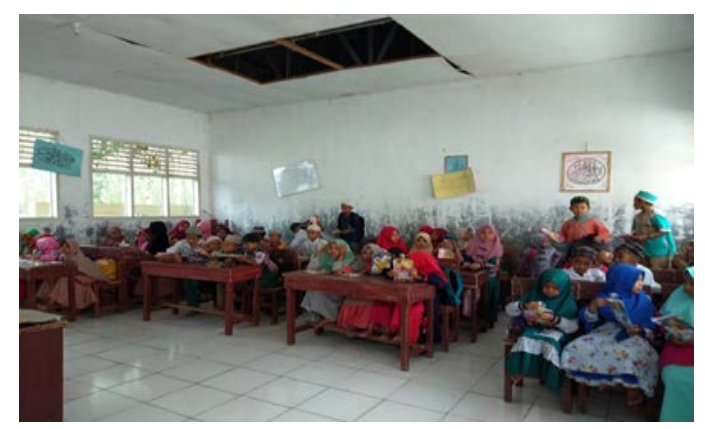

Gambar 1. Kondisi Mitra (Gambaran Siswa kurang Mampu di Desa Sialogo Kabupaten Tapanuli Selatan)

Desa Sialogo merupakan salah satu desa yang ada di Kabupaten
Tapanuli Selatan. Desa dengan kondisi jalan yang cukup berliku dan terdapat beberapa desa yang masih tergolong desa terpencil serta terdapat sekolah yang mengakomodir siswa-siswa di desa tersebut. Serta kondisi perekonomian yang masih di bawah rata-rata. Yang mengakibatkan menurunnya tingkat pendidikan serta kemampuan anak yang serba kekurangan. Dalam kegiatan pendidikan, guru memegang peranan yang sangat penting dalam mengembangkan kecakapan dan kepribadian siswa. Melalui pendidikan, siswa diharapkan mampu menyesuaikan diri dengan program akademik, tuntutan sosial dan tuntutan psikologis di lembaga pendidikan tempat ia mengembangkan dirinya.

Bimbingan belajar adalah suatu proses pemberian bantuan dari guru pembimbing kepada siswa dengan cara mengembangkan suasana belajar yang kondusif dan menumbuhkan kemampuan agar siswa terhindar dari dan atau dapat mengatasi kesulitan belajar yang mungkin dihadapinya sehingga mencapai hasil belajar yang optimal. Bimbingan belajar (layanan pembelajaran) mengisyaratkan pada tujuan intinya, yaitu memberikan kemungkinan yang seluas-luasnya pada siswa untuk mengembangkan sikap dan kebiasaan belajar yang baik, keterampilan dan materi belajar yang sesuai dengan tingkat kecepatan, kesulitan belajar, potensi, dan perkembangan diri siswa. Dengan demikian, fungsi utama dari layanan bimbingan belajar (layanan pembelajaran) adalah fungsi pemeliharaan dan pengembangan bagi siswa di sekolah (Suherman, 2019). Hal ini mengandung arti bahwa para guru pembimbing berupaya untuk memfasilitasi agar siswa dapat 
mengatasi kesulitan belajarnya dan sampai ada tujuan yang diharapkan.

\section{METODE PELAKSANAAN}

Bimbingan belajar yang berkualitas untuk siswa kurang mampu harus didasarkan pada teori belajar yang dapat membantu siswa untuk belajar mandiri. Adapun langkah-langkahnya adalah sebagai berikut:

1. Membagi ruangan menjadi 3 kelas. Setiap kelas masingmasing 5-6 orang. Yaitu kelas 4 , kelas 5 dan kelas 6

2. Peserta terdiri dari 20 orang.

3. Pelaksanaan 2 kali dalam seminggu dengan waktu 90 menit selama \pm 2 Bulan.

Selain itu salah satu aspek yang harus diperhatikan adalah pendataan siswa kurang mampu di desa. Aspek ini bertujuan untuk membantu siswa kurang mampu untuk mendapatkan pembelajaran yang lebih baik sehingga siswa dapat unggul dan tidak tertinggal dengan yang lainnya.

\section{HASIL DAN LUARAN YANG DICAPAI}

Kegiatan pelatihan ini terlaksana sesuai dengan yang diharapkan. Hal ini dapat dilihat dari Bulan pertama dan bulan kedua. Adapun hasil yang diperoleh dapat ditunjukkan berdasarkan pelaksanaan yang dilakukan dengan pembahasan sebagai berikut:

\section{Bulan Pertama}

Kegiatan di bulan pertama, dimana tim pengabdian masyarakat mendata seluruh anak-anak tingkat sekolah dasar yang berkategori kurang mampu (miskin) dan memotivasi para anak-anak untuk tidak bosan menambah ilmunya dengan mengikuti proses bimbingan belajar yang akan dilaksanakan selama pengabdian berlangsung. Guna untuk memperlancar kegiatan kita juga mengajak para orangtua agar ikut serta memotivasi anak-anak untuk terus belajar, sehingga apa yang diharapkan terwujud dengan baik dan tidak tertinggal dengan anakanak yang memiliki kesempatan mendapatkan pembelajaran tambahan di luar sekolah pada umumnya. Kegiatan ini dapat dikatakan terlaksana dengan baik hal ini didasari oleh antusias para peserta dalam mengikuti kegiatan serta dukungan dari para orangtua. Ini dapat ditunjukkan berdasarkan banyaknya anak-anak setiap harinya mengikuti bimbingan belajar.

\section{Bulan Kedua}

Kegiatan bimbingan belajar untuk bulan kedua merupakan bulan dalam menyelesaikan bimbingan belajar secara gratis. Dimana di bulan kedua ini peserta diminta untuk menyelesaikan soal-soal yang ada di sekolah mereka masing-masing yang dibimbing kebenarannya oleh mentor atau pendidik yang telah dipilih. Untuk lebih jelasnya di bawah ini merupakan salah satu jawaban yang dikerjakan peserta dalam menyelesaikan Pekerjan Rumah (PR) pada mata pelajaran Matematika:

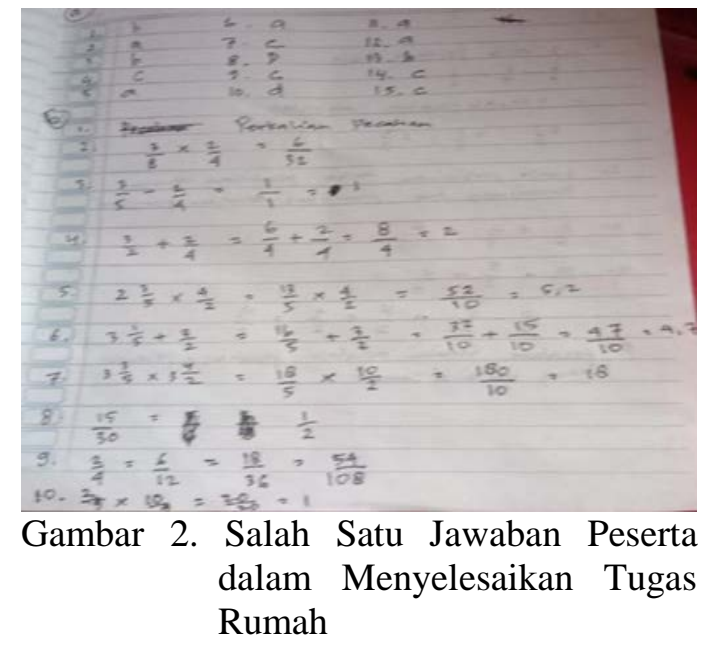


Berdasarkan hasil pengamatan dan hasil pelaksanaan maka kegiatan ini memberikan hal-hal yang baru bagi para peserta dan sekaligus memberikan manfaat yang besar untuk kemampuan belajar peserta, dimana sebelumnya para peserta belum pernah diberikan belajar tambahan seperti bimbingan belajar secara gratis. Kegiatan ini dapat dikatakan berhasil dan terlaksana hal ini juga di dasarkan pada antusias para peserta mengikuti kegiatan hingga akhir sehingga kegiatan yang dilaksanakan dapat terlaksana sesuai yang diharapkan.

Hasil dari bulan pertama dan bulan kedua menunjukkan bahwa kegiatan bimbingan belajar secara gratis dapat berjalan sesuai yang direncanakan. Ini didasarkan pada antusias peserta dalam mengikuti kegiatan dan mendengarkan materi yang disampaikan. Berdasarkan hal tersebut maka peserta yang pada umumnya anak-anak sekolah dasar di Desa Sialogo Kabupaten Tapanuli Selatan sudah banyak memperoleh motivasi, informasi terkait dalam pentingnya belajar. Jadi dimana pun dan kapanpun kita bisa belajar dan tidak cukup hanya di dapat selama di sekolah. Begitu juga anak-anak peserta bimbingan belajar bisa trus mengulang-ngulang pelajaran di rumah sekalipun bimbingan belajar ini telah selesai dilaksanakan. Sehingga harapan dari terlaksananya bimbingan belajar secara gratis ini dapat terlaksana dengan baik dan dapat memotivasi seluruh peserta untuk terus belajar.

\section{SIMPULAN}

Berdasarkan hasil kegiatan
bimbingan belajar yang sudah
dilakukan, maka diperoleh kesimpulan
sebagai berikut:

1. Diperoleh feedback yang positif dari pihak Pemerintah Desa, Orangtua dan peserta didik di Desa Sialogo Kabupaten Tapanuli Selatan selama mengikuti kegiatan.

2. Bertambahnya informasi, pengetahuan, dan pemahaman peserta tentang pentinganya belajar dan trus mengulang-ngulang pelajaran yang sudah dipelajari di sekolah.

3. Peserta sudah mampu dan paham dalam menyelesaikan soal-soal yang diberikan sekolah atau berupa Pekerjaan Rumah (PR) sendiri.

4. Tingginya motivasi yang dimiliki oleh Peserta dalam mengikuti kegiatan bimbingan belajar.

\section{DAFTAR PUSTAKA}

Suherman, M. P. 2019. "Bimbingan Belajar,” J. Chem. Inf. Model.

Syawie, M. 2011. "Kemiskinan dan Kesenjangan Sosial,” informasi. 